\title{
Dynamic multi-species occupancy models reveal individualistic habitat preferences in a high-altitude grassland bird community
}

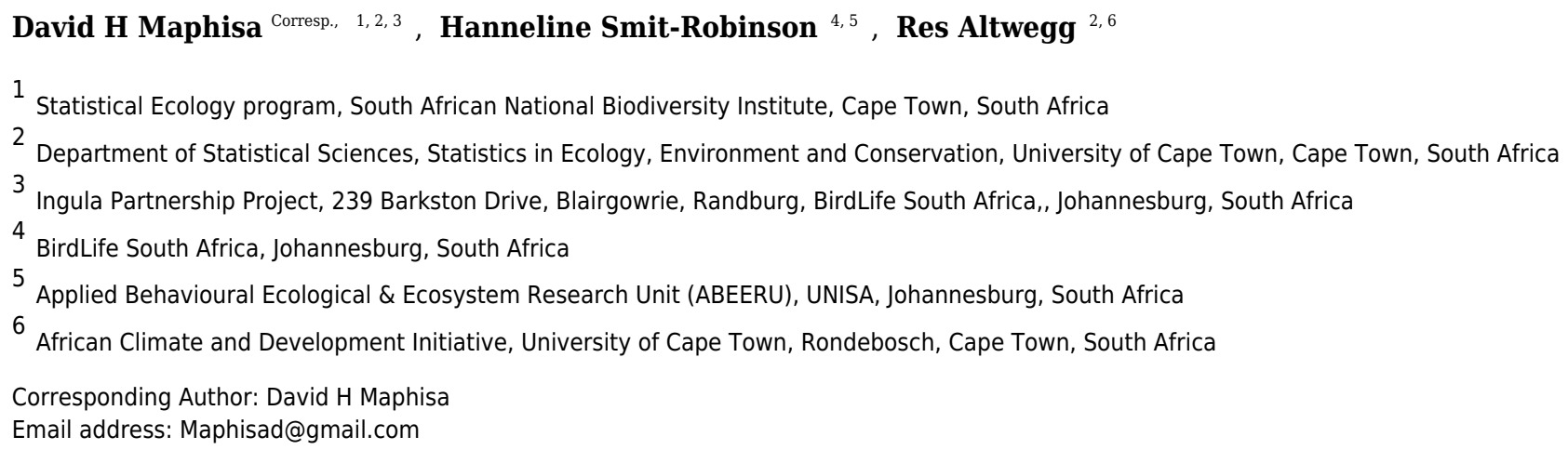

Moist, high-altitude grasslands of eastern South African harbour rich avian diversity and endemism. This area is also threatened by increasingly intensive agriculture and land conversion for energy production. This conflict is particularly evident at Ingula, an Important Bird and Biodiversity Area located within the least conserved high-altitude grasslands and which is also the site of a new Pumped Storage Scheme. The new management seeks to maximise biodiversity through manipulation of the key habitat variables: grass height and grass cover through burning and grazing to make habitat suitable for birds. However, different species have individual habitat preferences, which further vary through the season. We used a dynamic multi-species occupancy model to examine the seasonal occupancy dynamics of 12 common grassland bird species and their habitat preferences. We estimated monthly occupancy, colonisation and persistence in relation to grass height and grass cover throughout the summer breeding season of $2011 / 12$. For majority of these species, at the beginning of the season occupancy increased with increasing grass height and decreased with increasing grass cover. Persistence and colonisation decreased with increasing grass height and cover. However, the 12 species varied considerably in their responses to grass height and cover. Our results suggest that management should aim to provide plots which vary in grass height and cover to maximise bird diversity. We also conclude that the decreasing occupancy with increasing grass cover and low colonisation with increasing grass height and cover is a results of little grazing on our study site. We further conclude some of the 12 selected species are good indicators of habitat suitability more generally because they represent a range of habitat needs and are relatively easy to monitor. 
1 Dynamic multi-species occupancy models reveal individualistic habitat preferences 2 in a high-altitude grassland bird community.

3 David H. Maphisa*1, 2, 3, Hanneline Smit-Robinson 3, 4, 5, and Res 4 Altwegg 2, 6

$5 \quad{ }^{1}$ Statistical Ecology Program, South African National Biodiversity Institute, Private Bag X7,

6 Claremont 7735, South Africa; ${ }^{2}$ Statistics in Ecology, Environment and Conservation,

$7 \quad{ }^{2}$ Department of Statistical Sciences,Statistics in Ecology, Environment and Conservation,

8 University of Cape Town, Rondebosch 7701; South Africa

$9 \quad{ }^{3}$ Ingula Partnership Project, 239 Barkston Drive, Blairegowrie, Randburg, BirdLife South

10 Africa, Johannesburg South Africa

$11{ }^{4}$ BirdLife South Africa, Private Bag X5000 Parklands, 2121, South Africa

${ }^{5}$ Applied Behavioural Ecological \& Ecosystem Research Unit (ABEERU), UNISA, Private Bag

X6, Florida, 1717, South Africa

${ }^{6}$ African Climate and Development Initiative, University of Cape Town, Rondebosch 7701, South Africa;

Authoremail*Maphisad@gmail.com

\section{ABSTRACT}

Moist, high-altitude grasslands of eastern South African harbour rich avian diversity and endemism. This area is also threatened by increasingly intensive agriculture and land conversion for energy production. This conflict is particularly evident at Ingula, an Important Bird and Biodiversity Area located within the least conserved high-altitude grasslands and which is also the site of a new Pumped Storage Scheme. The new management seeks to maximise biodiversity through manipulation of the key habitat variables - grass height and grass cover - through burning and grazing to make habitat suitable for birds. However, it is not clear whether the key grassland species differ in habitat preferences, and how these preferences may vary through the season. We used a dynamic multi-species occupancy model to examine the seasonal occupancy dynamics of 12 common grassland bird species and their habitat preferences. We accounted for the influence of prevailing weather conditions and the day of survey on detection probabilities. We estimated plot occupancy, persistence and colonisation in relation to grass height and grass cover throughout the four summer breeding months. The majority of the studied species showed contrasting plot occupancy in relation to grass height and grass cover but overall heterogeneous plot persistence in relation to grass height and grass cover. In 9 out of the 12 species, colonisation declined with increasing grass height and grass cover. Our results suggest that management could increase bird diversity by increasing heterogeneity in grass height and cover, e.g. through the use of fire and grazing. We also conclude that the overall low colonisation with increasing grass height and cover is a result of reduced grazing on our study site. Finally, we conclude that some of the 12 selected species are good indicators of habitat suitability for monitoring suitability of habitat for co-occurring species of which we could not include because they are rare. 


\section{INTRODUCTION}

In South Africa the grassland biome and its associated biota are increasingly becoming threatened due to expansion of agricultural activities, human settlements and associated road infrastructure (Allan et al., 1997; Reyers et al., 2001; Egoh et al., 2011). The growth of the human population in southern Africa is accompanied by increasing demands for water and electricity. These pressures are likely to impact on bird species richness in remote eastern, moist, high-altitude grasslands (eg. Maphisa et al., 2016). This area is a centre of endemism for both plants and animals (Zunckel, 2003) and has the highest concentration of Important Bird and Biodiversity Areas (Barnes, 1998; Marnewick \& Retief, 2015) in southern Africa. These grasslands are currently predominantly used to support livestock farming accompanied by annual burning followed by heavy grazing (Maphisa et al., 2016, 2017). However, at the start of the 21 st century, the area is increasingly targeted for development of large water schemes (eg. Davies \& Day, 1998) and electricity projects to meet increasing demands for water for human consumption (Maphisa et al., 2016, 2017). The network of new roads to access these schemes and associated power grid in turn makes the area attractive for human settlement and intensification of agricultural activities. These developments, if not carefully planned, may result in habitat loss with possible negative impact on biodiversity in general.

Because of socio-political pressure and despite objections from environmental organisations, development in the area may not be completely prevented (Bennett et al., 2017). As a result of these threats facing mountain grassland habitats, there is now an urgent need for biodiversity information to identify and protect habitat for threatened fauna and flora of the area. As the pressure on the remaining natural land increases, these areas also need to be managed more effectively.

Before people started to use these grasslands intensively, herds of roaming wild antelopes are thought to have been responsible for creating a habitat mosaic that created niches for different bird species (Hockey et al., 1988). In recent times, planned man-made fires and grazing by domestic livestock have become important tools that grassland managers can use to manage grasslands for bird diversity. Grazing by mixed livestock and fires of different intensities create a habitat mosaic in grass height and cover which benefits a variety of species across the landscape at different times of the year (Hobbs \& Huenneke, 1992; Parr \& Chown, 2003; Tews et al., 2004; Vandvik et al., 2005; Fuhlendorf et al., 2006; Evans et al., 2006; Fahrig et al., 2011). Even though grass height and cover appear to be the two key variables determining habitat suitability 
72 for grassland bird species (Driscoll et al., 2010), we still have little information on how different 73 species react to grass height and cover throughout the breeding season.

Dynamic site occupancy models were initially developed as an approach to investigate the dynamics of species occurrence and to understand how factors of interest affect the vital rates that determine occurrence (rates of local persistence and colonization) (Mackenzie et al., 2011). Site occupancy models offer opportunities to frame and solve decision problems for conservation that can be viewed in terms of site occupancy (Royle \& Kéry, 2007; Martin et al., 2009) and are well suited for addressing management and conservation problems (Martin et al., 2009). Nondetection of a species at a site does not imply that the species is absent unless the detection probability is one (MacKenzie et al., 2003). Occupancy models account for imperfect detection, which is the inability of investigators to detect a species at a site with certainty (Zipkin, DeWan \& Royle, 2009). Incorporating detection probabilities into estimates of species richness is important for obtaining unbiased estimates of species numbers, particularly in communities with large numbers of rare or elusive species (Mackenzie et al., 2011; Govindan, Kéry \& Swihart, 2012; Oedekoven et al., 2013). Accounting for detectability is particularly important amongst grassland birds because many grassland birds are hard to identify or highly elusive.

In this study, we use repeated detection-non-detection data and state-space dynamic occupancy models, to evaluate how grass height and cover influence habitat use by 12 common bird species in high-altitude grassland in eastern South Africa throughout a breeding season. Grass height and cover are proximate factors influencing habitat selection and nest survival amongst grassland birds (Devereux et al., 2008; Whittingham \& Devereux, 2008; Cao et al., 2009; Donald et al., 2010; Fisher \& Davis, 2010; Klug, Jackrel \& With, 2010). Several species of conservation concern occur with conflicting habitat requirements in our study region (Maphisa et al., 2009, 2016). In the case where habitat is managed to maximize biodiversity, management actions that enhance habitat for some species may limit habitat for other species.

The goal of this study was to examine the response of 12 common grassland bird species to grass height and cover throughout an austral summer (2011/12) which coincides with high avian species richness and the time when most birds are breeding (Maphisa et al., 2016). We examined how grass height and cover was related to initial occupancy at the beginning of the 
101 breeding season, and how these two variables affected changes in habitat use throughout the 102 season.

103 MATERIALS AND METHODS

104 Study area

105 This study was conducted at Eskom Ingula Pumped Scheme property with a few plots randomly

106

107

108

109

110

111

112

113

114

115

116

117

118

119

120

121

122

123

124

125

126

127

128

129

130 selected from the neighbouring privately owned farms (Fig.1). Ingula is located c. $23 \mathrm{~km}$ northeast $\left(28^{\circ} 14^{\prime} \mathrm{S}, 29^{\circ} 35^{\prime} \mathrm{E}\right)$ of the village of Van Reenen at altitudes of 1200 to $1700 \mathrm{~m}$ asl and covers c. 8000 ha (Maphisa et al., 2016, 2017). It straddles the escarpment and two provinces: KwaZulu-Natal and Free State (FS). The average altitude below the escarpment is $1200 \mathrm{~m}$ asl and $1700 \mathrm{~m}$ asl above the escarpment. The FS side is dominated by sweet and sour grassland vegetation type (Mucina \& Rutherford, 2006), characterised by the grass Themeda triandra. The area below the escarpment is dominated by Hyparrhenia-Cybompogon grasses and has been modified into fields and alien plantations and therefore is considered of less conservation priority compared to the upper site (Maphisa et al., 2016).

Some parts of Ingula property (the area above the escarpment) and surrounding privately owned farms are designated an Important Bird and Biodiversity Area mainly because of high avian endemism (Marnewick et al., 2015). Previous land owners used annual fires to optimize domestic livestock production, the practice that over the years resulted to negative impact on ecosystem and biodiversity (Maphisa et al., 2016). Current Ingula management seeks scientific advice on how to reverse past harmful grassland management practices and make habitat suitable for unique fauna and flora of the area. The surrounding farms are still heavily grazed and annually burned with negative impact on habitats and species. This study was approved by the Ingula Partnership while DHM was an employee of Birdlife South Africa. The Ingula Partnership is made up of Birdlife South Africa, Middelpunt Wetland Trust and Eskom. DHM got further verbal permission from the neighboring farm owners to enter their properties and record birds and vegetation for the duration of this study. Commercial farmers' cattle were moved out of Ingula since summer of 2005 so that the area could recover from past heavy livestock grazing and annual burning. However, relatively small herds of livestock belonging to the former land owners' tenants remained on site throughout the duration of our study (Maphisa et al., 2016). 
The weather at Ingula is characterised by cold winters with occasional snow and strong directional winds and wet summers dominated by morning mist (Maphisa et al., 2016, 2017). Most of the rainfall occurs during the southern hemisphere summer (October to February), sometimes with marked rainfall differences between the upper and the lower parts of the study area. At Ingula, this sharp seasonal contrast in temperatures also affects bird species richness with highest species richness occurring in summer while the winters and spring recorded the lowest species richness (Maphisa et al., 2016). Therefore this study uses summer data for birds and vegetation when species richness is highest.

\section{Vegetation and bird surveys}

We laid a grid of $500 \mathrm{~m} \times 500 \mathrm{~m}$ on 1:50 000 topographic maps of the entire study area and extended the grid into adjacent neighbouring privately owned farms. We excluded all the plots that were steep or rocky. Slope aspects may compound our effort to associate grass height and cover to plot occupancy as birds tend to prefer certain slope aspects to others (Brambilla et al., 2013). Rocky outcrops also tend to be preferred by other types of birds that are none grassland birds. The topography of our study area is rugged (Maphisa et al., 2016) and bisected by other habitats other than just grassland (Fig. 1). We also excluded plots that were lying adjacent to the wetlands too to avoid associated edge effects (Bazzi et al., 2015). Then we sequentially numbered all the remaining plots and randomly selected 19 of them using the 'sample()' function in R (R Development Core Team, 2013). Twelve plots were located within the Ingula property itself and seven plots on neighbouring farms (Fig 1; plots P03A, P10, P50, P54, P57, P63, P64 were on private land).

On these plots we surveyed birds and vegetation during the austral summer of November 2011 to February 2012, spanning the entire breeding season. Within each plot we walked at constant pace along a continuous straight path inside each plot $150 \mathrm{~m}$ from the edge on three sides of the plot till we reached the forth side where we started. Each survey lasted 30 minutes. We recorded all birds that we saw inside the plot as we walked. Where grazing is excessive or grassland has been recently burned it is easy to see Common Quail Coturnix coturnix on the ground even when not calling (Maphisa et al., 2016). Except for Common Quail, we also recorded species based on call if the call clearly originated from within the plot limits. We assumed that walking rather than point counts would maximize detection of secretive grassland birds such as Yellow-breasted Pipit (Anthus Chloris) or Common Quail. The sighting and recording of birds was done by one 
162 person (DHM) with good experience of habitats of birds of this region. Each plot was visited

163

164

165

166

167

168

169

170

171

172

173

174

175

176

177

178

179

180

181

182

183

184

185

186

187

188

189

190

191

192 three times each month (November to February). Two of the surveys were undertaken mostly in the mornings, from 07h00-11h00, and sometimes in the afternoons from 15h00-16h00 when weather prevented completion of surveys during the morning (eg. Maphisa et al., 2016). Weather permitting, we ensured that the repeat surveys were very close to the first survey. During the third survey we also recorded vegetation characteristics in addition to birds and therefore survey mostly took a little longer than 30 minutes.

We recorded grass height and cover using similar methods as that of (Maphisa et al., 2009, 2017). We randomly placed a $30 \mathrm{~cm} \times 30 \mathrm{~cm}$ quadrat (divided into nine equal squares) twice every $100 \mathrm{~m}$ along the route where we had recorded birds earlier (Maphisa et al., 2017). We recorded grass cover as the number of squares with grass out of the total of nine squares in the frame. Each square that was at least $75 \%$ grass was considered grass. We recorded grass height at the four corners of the grid and averaged the four measurements for our analysis. This field protocol enabled the two variables to be measured over a relatively large area (Fig. 1). Weather conditions affect detectability of birds (Zuckerberg et al., 2011; Hovick, Elmore \& Fuhlendorf, 2014; Sliwinski et al., 2016). During each survey, we recorded cloud cover (clear, partly cloudy or cloudy) and temperature (cold, cool, warm or hot), together with wind conditions (calm, moderate or strong) (Harms et al., 2017). Because of our small data set, we wanted to reduce these weather covariates into a single variable representing observability. The variables were on an ordinal scale and to us, the most sensible way to reduce them to a single index was by subjectively scoring their effects based on our ability to detect birds (Appendix S1). The purpose of the observability covariate was simply to capture some of the variability in the detection probabilities, not to test any hypotheses about the detection process (Royle, 2006). No survey was carried out when poor visibility would impact the identification of birds.

In this study, we focused on the following 12 species, from the most common to the least common (based on preliminary data analysis): African Pipit Anthus cinnamomeus, Cape Longclaw Macronyx capensis, Wing-snapping Cisticola Cisticola ayresii, Red-capped Lark Calandrella cinerea, Zitting Cisticola Cisticola juncidis, Yellow-breasted Pipit, Common Quail, Long-tailed Widowbird Euplectes progne, African Quailfinch Ortygospiza atricolis, Banded Martin Riparia cincta, Ant-eating Chat Myrmecocichla formicivora and Eastern Long-billed Lark Certhilauda semitorquata. Of these species, the Yellow-breasted-Pipit is considered 
nationally threatened (Barnes, 2000; Taylor, Peacock \& Wanless, 2015). Our study area is home to other threatened species (Maphisa et al., 2016), but those were rare and resulted in low detections. The justification for choosing the 12 species above is that they are all typical grassland species with a diversity of habitat requirements (Maphisa et al., 2017) some of which could share habitat with rare species of management concern.

\section{Model description}

We used dynamic multi-species occupancy models to examine habitat use of 12 grassland bird species throughout their breeding season. The main habitat structuring factors we considered were grass height and cover. We were interested in the types of habitat each species occupied and how occupancy changed in relation to habitat from one month to the next over the course of a breeding season while accounting for imperfect detection. The basic idea is that (1) nondetection can be distinguished from absence through repeated sampling and (2) species-specific estimates of occurrence can be improved using collective data on all species observed during sampling (Zipkin et al., 2010). The dynamic model describes occupancy as a state process based on: (1) persistence: the probability of an occupied site continuing to be occupied from one month to the next, and (2) colonisation: the probability of an unoccupied site becoming colonised (Popescu et al., 2012).

We developed a multi-species hierarchical model (Appendix S2) using a state-space formulation (Royle \& Kéry, 2007). Our model assumes that site-specific occupancy (i.e. 'true' detection/nondetection) for species $i=1,2, \ldots, N$ at site $j=1,2 . ., J$, is denoted $z_{i, j}$, where $z_{i, j}=1$ if species i occurs at site $\mathrm{j}$ and otherwise $\mathrm{z}_{\mathrm{i}, \mathrm{j}}=0$ (Zipkin, DeWan \& Royle, 2009). Therefore, the occupancy status of species $\mathrm{i}$ at site $\mathrm{j}$ during repeat $\mathrm{k}$ visit month is represented by $\mathrm{z}_{\mathrm{i}, \mathrm{j}}$, where occupancy status of of each site is assumed to be constant across the three monthly repeat surveys. The occurrence status of each species is the stochastic binary outcome governed by the occupancy probability $(\Psi)$ of species $i$ at site $j$ which is assumed to be the outcome of Bernoulli random variables such that $\mathrm{z}_{\mathrm{i}, \mathrm{j}} \sim \operatorname{Bernoulli}(\Psi \mathrm{i}, \mathrm{j})$, the probability that species $\mathrm{i}$ is present at site $\mathrm{j}$ is represented by $\Psi \mathrm{i}, \mathrm{j}$ (Dorazio et al., 2006).

Similarly, we assumed that a species can only be detected at a site if it actually occurs there, i.e. there are no false positives (eg. Dorazio \& Royle, 2005; Dorazio et al., 2006). Therefore, detection of species $\mathrm{i}$ at site $\mathrm{j}$ on visit $\mathrm{k}$ is represented by detection probability $\mathrm{p}_{\mathrm{i}, \mathrm{j}, \mathrm{k}}$ with occupancy state: 
$224 \mathrm{x}_{\mathrm{i}, \mathrm{j}, \mathrm{k}} \sim \operatorname{Bernoulli}\left(\mathrm{p}_{\mathrm{i}, \mathrm{j}, \mathrm{k}} \times \mathrm{z}_{\mathrm{i}, \mathrm{j}, \mathrm{k}}\right)$.

225 (Dorazio et al., 2006; Russell et al., 2009; Zipkin, DeWan \& Royle, 2009).

226

227

228

229

230

231

232

233

234

235

236

237

238

239

240

241

242

243

244

245

246

247

248

249

250

251

252

253

254

We were interested in the seasonal changes in the bird communities and therefore we used a dynamic extension of the model above, allowing the occupancy status to change from one month to the next (eg. Iknayan et al., 2014). We modelled occupancy during the first month (November, $\mathrm{t}=1)$ as above,

$\mathrm{z}_{\mathrm{i}, \mathrm{j}, \mathrm{t}} \sim \operatorname{Bernoulli}\left(\Psi_{\mathrm{i}, \mathrm{j}}\right)$, for $\mathrm{t}=1$.

Occupancy during the subsequent months depended on occupancy during the preceding month:

$\mathrm{z}_{\mathrm{i}, \mathrm{j}, \mathrm{t}} \mid \mathrm{z}_{\mathrm{i}, \mathrm{j}, \mathrm{t}-1}, \varphi_{\mathrm{i}, \mathrm{j}, \mathrm{t}}, \gamma_{\mathrm{i}, \mathrm{j}, \mathrm{t}} \sim \operatorname{Bernoulli}\left(\varphi_{\mathrm{i}, \mathrm{j}, \mathrm{t}} \times \mathrm{Z}_{\mathrm{i}, \mathrm{j}, \mathrm{t}-1}+\gamma_{\mathrm{i}, \mathrm{j}, \mathrm{t}} \times\left(1-\mathrm{Z}_{\mathrm{i}, \mathrm{j}, \mathrm{t}-1)}\right)\right)$, for $\mathrm{t}>1$,

where the colonisation probability $(\gamma)$ is the probability of an unoccupied site becoming occupied and the persistence probability $(\varphi)$ is the probability of an occupied site remaining occupied (Royle \& Kéry, 2007). The occupancy probabilities during December, January and February $(\mathrm{t}=2,3$, and 4$)$ were calculated as derived parameters.

Initial occupancy, colonisation and persistence were constrained to be linear functions of the covariates grass height (avh) and grass cover (cover) on the logit scale:

$\operatorname{Logit}\left(\Psi_{\mathrm{i}, \mathrm{j}}\right)=\beta 0_{\mathrm{j}}+\beta 1_{\mathrm{j}} \times \operatorname{avh}_{\mathrm{i}, \mathrm{j}, \mathrm{t}}+\beta 2_{\mathrm{j}} \times \operatorname{cover}_{\mathrm{i}, \mathrm{j}, \mathrm{t}}$ for $\mathrm{t}=1$

$\operatorname{Logit}\left(\gamma_{i, j, t}\right)=v 0_{j}+v 1_{j} \times \operatorname{avh}_{i, j, t}+v 2_{j} \times \operatorname{cover}_{i, j, t} \quad$ for $t>1$

$\operatorname{Logit}\left(\varphi_{i, j, t}\right)=\mu 0_{j}+\mu 1_{j} \times \operatorname{avh}_{i, j, t}+\mu 2_{j} \times \operatorname{cover}_{i, j, t}$ for $\mathrm{t}>1$,

where the $\beta, v$ and $\mu$ are species-specific coefficients. Each of these nine coefficients was modelled as a separate random effect, i.e. $\eta_{\mathrm{i}} \sim \mathrm{N}\left(\eta_{-}\right.$bar, $\left.\sigma \eta\right)$ where $\eta_{-}$bar is the mean and $\sigma \eta$ the standard deviation of the species-specific coefficients and $\eta=\left\{\beta_{0,1,2}, v_{0,1,2}, \mu_{0,1,2}\right\}$.

As with occupancy (Kéry et al., 2009; Russell et al., 2009),we incorporated factors that influence detection of each species during each site visit. We modelled the detection probability (p) as a function of conditions measured by the continuous covariates obs (appendix), and as a function of the day of the survey (day: the number of days since the start of the season). $\alpha 0, \alpha 1$ and $\alpha 2$ as coefficients:

$\operatorname{Logit}\left(\mathrm{p}_{\mathrm{i}, \mathrm{j}, \mathrm{k}, \mathrm{t}}\right)=\alpha 0+\alpha 1$ obs $_{\mathrm{i}, \mathrm{j}, \mathrm{k}, \mathrm{t}}+\alpha 2$ day $_{\mathrm{i}, \mathrm{j}, \mathrm{k}, \mathrm{t}} \quad$ (Zipkin, DeWan \& Royle, 2009; Zipkin et al., 2010)

Each of the three coefficients was modelled as a separate random effect, i.e. $\alpha_{j} \sim \mathrm{N}\left(\alpha_{-}\right.$bar, $\left.\sigma_{\alpha}\right)$ where $\alpha \_$bar is the mean and $\sigma_{\alpha}$ the standard deviation of the species-specific coefficients. 
255 Each covariate was centred and scaled before analysis (Nichols \& Boulinier, 1998; van den Berg 256 et al., 2006; Jones et al., 2012; Pollock et al., 2014). We then calculated the number of species 257 (Dorazio et al., 2006; Zipkin, DeWan \& Royle, 2009), out of the 12 studied species, that are 258 present at a site in a given month (local species richness, $\left.r_{i, t}=\Sigma \mathrm{jzi}, \mathrm{j}, \mathrm{t}\right)$ and the number of plots each 259

260 261

262

263

264

265

266

267

268

269

270

271

272

273

274

275

276

277

278

279

280

281

282

283

284

285 species occupied in a given month $\left(\mathrm{oj}, \mathrm{t}=\sum_{\mathrm{iz}} \mathrm{i}, \mathrm{j}, \mathrm{t}\right)$ as derived parameters.

\section{Model fitting and analysis}

We estimated the parameters using a Bayesian analysis of the model with vague priors (Royle \& Kéry, 2007; Russell et al., 2009; Zipkin, DeWan \& Royle, 2009; Banks-Leite et al., 2014) for all parameters. We used a flat normal distribution $\mathrm{N}(0,100)$ for the means of the coefficients and Inverse Gamma $(0.01,0.01)$ for the variances of the random effects. We tested the sensitivity to the choice of priors for the latter by also using $\mathrm{U}(0,15)$ as priors for the standard deviations (Zipkin, DeWan \& Royle, 2009) (Appendix S2).

We carried out the analysis in JAGS (Plummer, 2003) called via package rjags (Plummer, 2014) from R (R Development Core Team, 2013). The MCMC procedure requires an initial burn-in period for the chains to converge to a stationary process, after which the subsequent estimates can be used to calculate medians and credible intervals associated with the parameters of interest (Sauer et al., 2013). We assessed convergence by verifying that the Gelman-Rubin statistic was below 1.1 (Brooks \& Gelman, 1998; Gelman \& Shirley, 2011) and visual inspection of the chains (Jones et al., 2012). We ran three chains of length 60000 each; with a burn-in of 30 000 and thinned the remaining results by taking each 20th value from the chains. With these settings, the model converged for all parameters.

\section{RESULTS}

The detection probabilities varied among species and increased with increasing magnitude of our observability covariate for most species, indicating that the variable captured some of the variability in detection probabilities (Fig. 2). For most species, the detection probability also increased over the course of the season (Fig. 2).

\section{Species occupancy phenology over the four months}

Plot occupancy was variable among the 12 species across the four months, with overall high initial occupancy followed by a gradual decline in the number of occupied plots for a majority of the 12 species as the season progressed (Fig. 3). The Wing-snapping Cisticola was recorded in almost every plot throughout the four months and occupancy for this species was estimated to be 
286

287

288

289

290

291

292

293

294

295

296

297

298

299

300

301

302

303

304

305

306

307

308

309

310

311

312

313

314

315

1. Four other species, Cape Longclaw, African Pipit, Zitting Cisticola and Banded Martin, exhibited high plot occupancy too throughout the four months. Three other species were common early during the season but showed a rapid decline to a low number of occupied plots by the fourth month (number of occupied plots in November minus number of occupied plots in February [95\% credible interval]: Red-capped Lark 14 [12, 15]; Common Quail $11[5,16]$, Yellow-breasted Pipit 9 [5, 11]). Long-tailed Widowbird and Eastern Long-billed Lark occupied the fewest number of plots throughout the season, with Eastern Long-billed Lark showing a rapid decline between the third and fourth months (Fig. 3, number of occupied plots in January minus number of occupied plots in February $7[0,10])$.

\section{Effects of habitat on occupancy, persistence and colonisation}

On average across species, initial occupancy increased with increasing grass height and decreased with increasing grass cover (heavy black lines in Fig. 4). The species therefore tended to prefer relatively open plots with high grass at the beginning of the breeding season. Over the course of the season, they tended to have a higher persistence on patches with short grass and little cover, and were more likely to colonize such plots. However, there was considerable variation among species in their responses to grass height and cover.

One group of species (Cape Longclaw, Wing-snapping Cisticola, Zitting Cisticola and Banded Martin) occurred on most plots throughout the season and consequently showed little sensitivity to grass height and cover. Long-tailed Widowbird and Eastern Long-billed Lark were two of the species with the strongest preference for plots with open and high grass, and they tended to persist better in such plots. Among the two species that showed biggest decline in occupancy through the season, Red-Capped Lark was more likely to persist on plots with short and open grass, whereas Common Quail had relatively higher persistence on plots with short and dense grass. Of the two species that tended to increase occupancy over the season, African Quailfinch was more likely to colonise plots with short dense grass and Long-tailed Widowbird was more likely to colonise plots with short and open grass.

\section{Species richness: comparing Ingula with neighbouring private farms.}

Species richness did not vary much over the four summer months and was similar on Eskom's property compared to neighbouring private farms in November (difference [95\% credible 
316 interval] in species richness: $0.5[-0.3,1.3])$ and December $(-0.3[-0.9,0.3])$ but slightly higher

317 on private land in January $(1.2[0.5,1.8]$ and February $(0.8[0.1,1.5]$, Fig. 5).

318

319

320

321

322

323

324

325

326

327

328

329

330

331

332

333

334

335

336

337

338

339

340

341

342

343

344

345

346

\section{DISCUSSION}

The primary aim of our study was to investigate how grass height or grass cover or both potentially affect plot occupancy by the 12 common grassland birds of our study. Our results are consistent with earlier studies demonstrating an avifaunal shift in response to change in vegetation height (Martin \& Possingham, 2005; Tichit et al., 2007; García et al., 2007) as season progresses. Both grass height and cover are proximate factors which, when managed with fire and grazing, create habitat suitability for birds of contrasting habitat needs (Fuhlendorf, Engle \& Moreira, 2004; Maphisa et al., 2016, 2017). Our results are consistent with the results of previous studies showing that a habitat mosaic in grass height and cover can allow species differing in habitat needs to occur in the same area (Fuhlendorf, Engle \& Moreira, 2004; Coppedge et al., 2008; Hovick, Elmore \& Fuhlendorf, 2014). We therefore suggest that the management of this grasslands use fire and grazing pro-actively to increase habitat suitability that would benefit species of contrasting habitat requirements (Fuhlendorf et al., 2009). Such management should also benefit rare species for which we did not have enough data to include in this analysis.

We examined how environmental factors and the time of day in our austral summer season affect detection of selected typical grassland birds. We found the detection of the following species showing pronounced decline with season (African Pipit, Long-tailed Widowbird, African Qualifinch and Ant-eating Chat) in an environment where the breeding season is short and birds undertake local altitudinal migration (Berruti, Harrison \& Navarro, 1994). Some species could be harder to detect later in the season because they are less active when breeding or as grass height grows taller compared to early in the season (Furnas \& McGrann, 2018; Grinde, Niemi \& Etterson, 2018) in an area which is mostly annually burned before summer (Maphisa et al., 2016, 2017). Overall, our results on effect of weather and date of survey in a season seem to largely support each other (eg. Fig. 2).

Amongst this species, the threatened Yellow-breasted Pipit and Red-capped Lark could serve as indicators of habitat suitability for other species under managed grazing and burning. For example, although Yellow-breasted Pipit indicate a high initial plot occupancy (Fig.3) and high plot occupancy across average grass heights (Fig. 4), this species reacts negatively to increase in grass cover (Fig. 4). This indicate a need for controlled grazing post burning to open up patches 
347 for feeding and nesting. Initially, Red-capped Lark indicates a high plot occupancy (Fig. 3\&4)

348 but low persistence with increasing grass height and grass cover. Therefore, high plot occupancy 349 of this species during mid-season when birds are breeding, would indicate that average grass 350 height is too short and open, indicating overgrazing. Overgrazing leads to low nest survival amongst grassland birds and it must be avoided in this grasslands (Maphisa et al., 2009).

The increasing demand for land for development necessitates more effective management of the remaining ecosystems and biodiversity (Zipkin, DeWan \& Royle, 2009; Drum et al., 2015). Detection-nondetection data and multi-species occupancy models (MacKenzie et al., 2003; Popescu et al., 2012) provide a cost effective way of studying the response of a collection of species for management of the habitat (Sauer et al., 2013).

We modelled occupancy, persistence and colonisation as logit-linear functions of grass height and cover from one month to the next for four months (multi-seasons). This was a simple approach. An alternative approach would have been to consider models with quadratic terms (Zipkin, DeWan \& Royle, 2009; Zipkin et al., 2010; Ruiz-Gutiérrez, Zipkin \& Dhondt, 2010) to examine species-specific optima in grass height and cover. However, we did not do this due to small sample size (12 plots within Ingula compared to 7 on private land), which was a result of the study site rugged topography and the fact that the surveys were undertaken by one person. Even with five plots short, the mean species richness comparing the two differently managed sites is about the same. This is because each farmer on the neighbouring farms applies fire and stocking densities differently and therefore provides heterogeneity in grass height and cover which would benefit different species.

Hierarchical multi-species occupancy models that require detection-nondetection data (eg. Goijman et al., 2015) have advantage compared to other methods (eg Maphisa et al., 2017) for monitoring purposes because only presence/absence of species is recorded. Repeated surveys provide important information on the observation process (Kery, Guillera-Arroita \& LahozMonfort, 2013; Sauer et al., 2013). The difficult topography of our study area plus inclement weather made it difficult to have large sample size. However, despite the small number of plots surveyed, our findings have provided management of these grasslands with important vegetation attributes that needs to be manipulated with fire and grazing to make habitat suitable for birds. Recent improvements in hierarchical multi-species dynamic occupancy models (eg. Bailey, Mackenzie \& Nichols, 2014) makes it possible during monitoring to predict areas that may not 
378 be sampled in some years due to logistic factors such as inclement weather (eg. Iknayan et al., 379 2014).

380 ACKNOWLEDGEMENTS

381 We are greatly indebted to Sakhile Wiseman Mthalane who assisted (DHM) during fieldwork. 382 Also we would like to thank farmers whose property boarders Ingula and allowed us unrestricted 383 access to their land during our field work surveys. We thank Prof Les Underhill for providing 384 the critique that helped us to make improvements on our original manuscript. We are greatly 385 indebted to Malcolm Drummond for proofreading the original manuscript and providing 386 comments. 


\section{LITERATURE CITED}

Allan DG., Harrison JA., Navarro RA., van Wilgen BW., Thompson MW. 1997. The impact of commercial afforestation on bird populations in Mpumalanga Province, South Africa insights from bird-atlas data. Biological Conservation 79:173-185.

Bailey LL., Mackenzie DI., Nichols JD. 2014. Advances and applications of occupancy models. Methods in Ecology and Evolution 5:1269-1279. DOI: 10.1111/2041-210X.12100.

Banks-Leite C., Pardini R., Boscolo D., Cassano CR., Puttker T., Barros CS., Barlow J. 2014. Assessing the utility of statistical adjustments for imperfect detection in tropical conservation science. Journal of Applied Ecology 51:849-859. DOI: 10.1111/13652664.12272.

Barnes K. 1998. The Important Bird Areas of Southern Africa. Johannesburg, South Africa: BirdLife South Africa.

Barnes K. 2000. The Eskom Red data book of birds of South Africa, Lesotho and Swaziland. Johannesburg, South Africa: BirdLife South Africa.

Bazzi G., Foglini C., Brambilla M., Saino N., Rubolini D. 2015. Habitat management effects on Prealpine grassland bird communities. Italian Journal of Zoology 82:251-261. DOI: 10.1080/11250003.2014.983566.

Bennett NJ., Roth R., Klain SC., Chan K., Christie P., Clark DA., Cullman G., Curran D., Durbin TJ., Epstein G., Greenberg A., Nelson MP., Sandlos J., Stedman R., Teel TL., Thomas R., Veríssimo D., Wyborn C. 2017. Conservation social science : Understanding and integrating human dimensions to improve conservation. Biological Conservation 205:93108. DOI: 10.1016/j.biocon.2016.10.006.

van den Berg RA., Hoefsloot HCJ., Westerhuis JA., Smilde AK., Werf MJ Van Der. 2006. Centering, scaling, and transformations : improving the biological information content of metabolomics data. BMC Genomics 15:1-15. DOI: 10.1186/1471-2164-7-142.

Berruti A., Harrison JA., Navarro RA. 1994. Seasonal migration of terrestrial birds along the southern and eastern coast of southern Africa. Ostrich 65:54-65.

Brambilla M., Fulco E., Gustin M., Celada C. 2013. Habitat preferences of the threatened Blackeared Wheatear Oenanthe hispanica in southern Italy. Bird Study 60:432-435. DOI: 10.1080/00063657.2013.819831.

Brooks SPB., Gelman AG. 1998. General methods for monitoring convergence of iterative simulations. Journal of computational and graphical statistics 7:434-455. DOI: $10.2307 / 1390675$.

Cao J., He CZ., Suedkamp Wells KM., Millspaugh JJ., Ryan MR. 2009. Modeling age and nestspecific survival using a hierarchical bayesian approach. Biometrics 65:1052-1062. DOI: 10.1111/j.1541-0420.2009.01204.x.

Concepción ED., Díaz M., Kleijn D., Báldi A., Batáry P., Clough Y., Gabriel D., Herzog F., Holzschuh A., Knop E., Marshall EJP., Tscharntke T., Verhulst J. 2012. Interactive effects of landscape context constrain the effectiveness of local agri-environmental management. Journal of Applied Ecology 49:695-705. DOI: 10.1111/j.1365-2664.2012.02131.x.

Coppedge BR., Fuhlendorf SD., Harrell WC., Engle DM. 2008. Avian community response to vegetation and structural features in grasslands managed with fire and grazing. Biological Conservation 141:1196-1203. DOI: 10.1016/j.biocon.2008.02.015.

Davies B., Day J. 1998. Vanishing waters. Cape Town: University of Cape Town press.

Devereux CL., Fernandez-Juricic E., Krebs JR., Whittingham MJ. 2008. Habitat affects escape behaviour and alarm calling in Common Starlings Sturnus vulgaris. Ibis 150:191-198. DOI: 
10.1111/j.1474-919X.2008.00835.x.

Donald PF., Buchanan GM., Collar NJ., Dellelegn Abebe Y., Gabremichael MN., Mwangi MAK., Ndang'Ang'a PK., Spottiswoode CN., Wondafrash M. 2010. Rapid declines in habitat quality and population size of the Liben (Sidamo) Lark Heteromirafra sidamoensis necessitate immediate conservation action - ERRATUM. Bird Conservation International 20:1-12. DOI: 10.1017/S095927091000033X.

Dorazio R., Royle J. 2005. Estimating size and composition of biological communities by modeling the occurrence of species. Journal of the American Statistical Association 100:389-398.

Dorazio RM., Royle JA., Söderström B., Glimskär A. 2006. Estimating species richness and accumulation by modeling species occurence and detectability. Ecology 87:842-854.

Driscoll DA., Lindenmayer DB., Bennett AF., Bode M., Bradstock RA., Cary GJ., Clarke MF., Dexter N., Fensham R., Friend G., Gill M., James S., Kay G., Keith DA., MacGregor C., Russell-Smith J., Salt D., Watson JEM., Williams RJ., York A. 2010. Fire management for biodiversity conservation: Key research questions and our capacity to answer them. Biological Conservation 143:1928-1939. DOI: 10.1016/j.biocon.2010.05.026.

Drum RG., Ribic CA., Koch K., Lonsdorf E., Grant E., Ahlering M., Barnhill L., Dailey T., Lor S., Mueller C., Pavlacky DC., Rideout C., Sample D. 2015. Strategic grassland bird conservation throughout the annual cycle: Linking policy alternatives, landowner decisions, and biological population outcomes. PLOS ONE 10:1-16. DOI:

10.1371/journal.pone.0142525.

Egoh BN., Reyers B., Rouget M., Richardson DM. 2011. Identifying priority areas for ecosystem service management in South African grasslands. Journal of Environmental Management 92:1642-50. DOI: 10.1016/j.jenvman.2011.01.019.

Evans DM., Redpath SM., Evans SA., Elston DA., Gardner CJ., Dennis P., Pakeman RJ. 2006. Low intensity, mixed livestock grazing improves the breeding abundance of a common insectivorous passerine. Biology Letters 2:636-8. DOI: 10.1098/rsbl.2006.0543.

Fahrig L., Baudry J., Brotons L., Burel FG., Crist TO., Fuller RJ., Sirami C., Siriwardena GM., Martin J-L. 2011. Functional landscape heterogeneity and animal biodiversity in agricultural landscapes. Ecology Letters 14:101-12. DOI: 10.1111/j.14610248.2010.01559.x.

Fisher RJ., Davis SK. 2010. From Wiens to Robel: A review of grassland-bird habitat selection. Journal of Wildlife Management 74:265-273. DOI: 10.2193/2009-020.

Fuhlendorf SD., Engle DM., Kerby J., Hamilton R. 2009. Pyric herbivory: rewilding landscapes through the recoupling of fire and grazing. Conservation Biology 23:588-98. DOI: 10.1111/j.1523-1739.2008.01139.x.

Fuhlendorf SD., Engle DM., Moreira SD. 2004. Application of the fire- $\square$ grazing interaction to restore a shifting mosaic on tallgrass prairie. Journal of Applied Ecology 41:604-614. DOI: 10.1111/j.0021-8901.2004.00937.x.

Fuhlendorf SD., Harrell WC., Engle DM., Hamilton RG., Davis CA., Leslie DM. 2006. Should heterogeneity be the basis for conservation? Grassland bird response to fire and grazing. Ecological Applications 16:1706-1716.

Furnas BJ., McGrann MC. 2018. Using occupancy modeling to monitor dates of peak vocal activity for passerines in California. The Condor 120:188-200. DOI: 10.1650/CONDOR17-165.1.

García C., Renison D., Cingolani AM., Fernández-Juricic E. 2007. Avifaunal changes as a 
consequence of large-scale livestock exclusion in the mountains of Central Argentina. Journal of Applied Ecology 45:351-360. DOI: 10.1111/j.1365-2664.2007.01388.x. Gelman A., Shirley K. 2011. Inference from simulations and monitoring convergence. In: Brookes S, Gelman A, Galin J, Meng Xiao-Li eds. Handbook of Markove Chain Monte Carlo: Chapman \& Hall/CRC Handbooks of modern statistical methods. CRC Press 2011, 163-174.

Goijman AP., Conroy MJ., Bernardos JN., Zaccagnini ME. 2015. Multi-season regional analysis of multi-species occupancy: Implications for bird conservation in agricultural lands in eastcentral Argentina. PLOS ONE 10. DOI: 10.1371/journal.pone.0130874.

Govindan B., Kéry M., Swihart R. 2012. Host selection and responses to forest fragmentation in acorn weevils: inferences from dynamic occupancy models. Oikos 121:623-633. DOI: 10.1111/j.1600-0706.2011.19747.x.

Grinde AR., Niemi GJ., Etterson MA. 2018. Effects of experimental playbacks on availability for detection during point counts. Journal of Field Ornithology 89:93-104. DOI: 10.1111/jofo.12242.

Harms TM., Murphy KT., Lyu X., Patterson SS., Kinkead E., Dinsmore SJ., Frese PW. 2017. Using landscape habitat associations to prioritize areas of conservation action for terrestrial birds. PLoS ONE 12:e0173041. DOI: 10.1371/journal.pone.0173041.

Hobbs RJ., Huenneke LF. 1992. Disturbance and invasion implications for conservation. Conservation Biology 6:324-337.

Hockey PAR., Allan DG., Rebelo AG., Dean WRJ., Rabelo AG. 1988. The distribution, habitat requirements and conservation status of Rudd's Lark Heteromirafra ruddi in South Africa. Biological Conservation 45:255-266.

Hovick TJ., Elmore RD., Fuhlendorf SD. 2014. Structural heterogeneity increases diversity of non-breeding grassland birds. Ecosphere 5:1-13. DOI: 10.1890/ES14-00062.1.

Iknayan KJ., Tingley MW., Furnas BJ., Beissinger SR. 2014. Detecting diversity: Emerging methods to estimate species diversity. Trends in Ecology and Evolution 29:97-106. DOI: 10.1016/j.tree.2013.10.012.

Jones JE., Kroll AJ., Giovanini J., Duke SD., Ellis TM., Betts MG. 2012. Avian species richness in relation to intensive forest management practices in early seral tree plantations. PLoS ONE 7:e43290. DOI: 10.1371/journal.pone.0043290.

Kery M., Guillera-Arroita G., Lahoz-Monfort JJ. 2013. Analysing and mapping species range dynamics using occupancy models. Journal of Biogeography 40:1463-1474. DOI: $10.1111 /$ jbi.12087.

Kéry M., Royle JA., Plattner M., Dorazio RM. 2009. Species richness and occupancy estimation in communities subject to temporary emigration. Ecology 90:1279-1290.

Klug PE., Jackrel SL., With KA. 2010. Linking snake habitat use to nest predation risk in grassland birds: the dangers of shrub cover. Oecologia 162:803-13. DOI: 10.1007/s00442009-1549-9.

Mackenzie DI., Bailey LL., Hines JE., Nichols JD. 2011. An integrated model of habitat and species occurrence dynamics. Methods in Ecology and Evolution 2:612-622. DOI: 10.1111/j.2041-210X.2011.00110.x.

MacKenzie DI., Nichols JD., Hines JE., Knutson MG., Franklin AB. 2003. Estimating site occupancy, colonization, and local extinction when a species is detected imperfectly. Ecology 84:2200-2207.

Mamo Y., Asefa A., Mengesha G. 2016. Effects of livestock grazing on an Afromontane 
grassland bird community in the Bale Mountains of Ethiopia. African Journal of Ecology 54:1-8. DOI: 10.1111/aje.12295.

Maphisa DH., Donald PF., Buchanan GM., Ryan PG. 2009. Habitat use, distribution and breeding ecology of the globally threatened Rudd's Lark and Botha's Lark in eastern South Africa. Ostrich 80:19-28. DOI: 10.2989/OSTRICH.2009.80.1.3.761.

Maphisa DH., Robinson HS., Underhill LG., Altwegg R. 2017. Management factors affecting densities of common grassland birds of high elevation grasslands of eastern South Africa : Ingula as a case study. Avian Research:1-13. DOI: 10.1186/s40657-017-0063-8.

Maphisa DH., Smit-robinson H., Underhill LG., Altwegg R. 2016. Drivers of Bird Species Richness within Moist High-Altitude Grasslands in Eastern South Africa. PlosOne 11:e0162609. DOI: 10.1371/journal.pone.0162609.

Marnewick M., Retief E. 2015. South Africa's Important Bird and Biodiversity Areas Status Report. Birdlife South Africa, Johannesburg, South Africa.

Marnewick M., Retief E., Theron N., Wright D., Anderson T. 2015. Important bird and biodiversity areas of Southern Africa. Johannesburg, South Africa: BirdLife South Africa.

Martin J., McIntyre CL., Hines JE., Nichols JD., Schmutz J a., MacCluskie MC. 2009. Dynamic multistate site occupancy models to evaluate hypotheses relevant to conservation of Golden Eagles in Denali National Park, Alaska. Biological Conservation 142:2726-2731. DOI: 10.1016/j.biocon.2009.06.027.

Martin TG., Possingham HP. 2005. Predicting the impact of livestock grazing on birds using foraging height data. Journal of Applied Ecology 42:400-408. DOI: 10.1111/j.13652664.2005.01012.x.

Mucina L., Rutherford M. 2006. The vegetation of South Africa, Lesotho and Swaziland. Pretoria: South African National Biodiversity Institute.

Neke KS., Du Plessis M. 2004. The threat of transformation: quantifying the vulnerability of grasslands in South Africa. Conservation Biology 18:466-477.

Nichols J., Boulinier T. 1998. Estimating rates of local species extinction, colonization, and turnover in animal communities. Ecological Applications 8:1213-1225.

Oedekoven CS., Buckland ST., Mackenzie ML., Evans KO., Burger LW. 2013. Improving distance sampling: accounting for covariates and non-independency between sampled sites. Journal of Applied Ecology 50:786-793. DOI: 10.1111/1365-2664.12065.

Parr CL., Chown SL. 2003. Burning issues for conservation: A critique of faunal fire research in Southern Africa. Austral Ecology 28:384-395. DOI: 10.1046/j.1442-9993.2003.01296.x.

Plummer M. 2003. JAGS : A Program for Analysis of Bayesian Graphical Models Using Gibbs Sampling JAGS : Just Another Gibbs Sampler. Proceedings of the 3rd International Workshop on Distributed Statistical Computing (DSC 2003):March 20-22, Vienna, Austria. ISSN 1609-395X. DOI: 10.1.1.13.3406.

Plummer M. 2014. Bayesian graphical models using MCMC, R package version 3-12. available at:http://CRAN.Rproject.org/package=rjags.

Pollock LJ., Tingley R., Morris WK., Golding N., Hara RBO., Parris KM., Vesk PA., Mccarthy MA. 2014. Understanding co-occurrence by modelling species simultaneously with a Joint Species Distribution Model ( JSDM ). Methods in Ecology and Evolution 5:397-406. DOI: 10.1111/2041-210X.12180.

Popescu VD., de Valpine P., Tempel D., Peery MZ. 2012. Estimating population impacts via dynamic occupancy analysis of Before-After Control-Impact studies. Ecological Applications 22:1389-404. 
572

573

574

575

576

577

578

579

580

581

582

583

584

585

586

587

588

589

590

591

592

593

594

595

596

597

598

599

600

601

602

603

604

605

606

607

608

609

610

611

612

613

614

615

616

617

R Development Core Team. 2013. R: A language and environment for statistical computing. R Foundation for Statistical Computing. Vienna, Austria. URL http://www.R-project.org/.

Reyers B. 2001. Priority areas for the conservation of South African vegetation: a coarse-filter approach. Diversity and Distributions 7:79-95.

Reyers B., Fairbanks DHK., Van Jaarsveld AS., Thompson M. 2001. Priority areas for the conservation of South African vegetation: a coarse-filter approach. Diversity and Distributions 7:79-95.

Royle JA. 2006. Site occupancy models with heterogeneous detection probabilities. Biometrics 62:97-102. DOI: 10.1111/j.1541-0420.2005.00439.x.

Royle JA., Kéry M. 2007. A Bayesian state-space formulation of dynamic occupancy models. Ecology 88:1813-23.

Ruiz-Gutiérrez V., Zipkin EF., Dhondt AA. 2010. Occupancy dynamics in a tropical bird community: unexpectedly high forest use by birds classified as non-forest species. Journal of Applied Ecology 47:621-630. DOI: 10.1111/j.1365-2664.2010.01811.x.

Russell RE., Royle JA., Saab VA., Lehmkuhl JF., Block WM., Sauer JR. 2009. Modeling the effects of environmental disturbance on wildlife communities: avian responses to prescribed fire. Ecological Applications 19:1253-63.

Sauer JR., Blank PJ., Zipkin EF., Fallon JE., Fallon FW. 2013. Using multi-species occupancy models in structured decision making on managed lands. The Journal of Wildlife Management 77:117-127. DOI: 10.1002/jwmg.442.

Sliwinski M., Powell LA., Sliwinski M., Powell L., Koper N., Giovanni M., Schacht W. 2016. Research design considerations to ensure detection of all species in an avian community Research design considerations to ensure detection of all species in an avian community. Methods in Ecology and Evolution 7:456-462. DOI: 10.1111/2041-210X.12506.

Taylor M., Peacock F., Wanless R. 2015. The 2015 Eskom Red Data Book of Birds of South Africa, Lesotho and Swaziland. Johannesburg, South Africa: BirdLife South Africa.

Tews J., Brose U., Grimm V., Tielbörger K., Wichmann MC., Schwager M., Jeltsch F. 2004. Animal species diversity driven by habitat heterogeneity/diversity: the importance of keystone structures. Journal of Biogeography 31:79-92.

Tichit M., Doyen L., Lemel JY., Renault O., Durant D. 2007. A co-viability model of grazing and bird community management in farmland. Ecological Modelling 206:277-293.

Vandvik V., Heegaard E., Maren IE., Aarrestad PA. 2005. Managing heterogeneity: the importance of grazing and environmental variation on post-fire succession in heathlands. Journal of Applied Ecology 42:139-149.

Whittingham MJ., Devereux CL. 2008. Changing grass height alters foraging site selection by wintering farmland birds. Basic and Applied Ecology 9:779-788. DOI: 10.1016/j.baae.2007.08.002.

Zipkin EF., Andrew Royle J., Dawson DK., Bates S. 2010. Multi-species occurrence models to evaluate the effects of conservation and management actions. Biological Conservation 143:479-484. DOI: 10.1016/j.biocon.2009.11.016.

Zipkin EF., DeWan A., Royle J. 2009. Impacts of forest fragmentation on species richness: a hierarchical approach to community modelling. Journal of Applied Ecology 46:815-822. DOI: 10.1111/j.1365-2664.2009.01664.x.

Zuckerberg B., Bonter DN., Hochachka WM., Koenig WD., Degaetano AT., Dickinson JL. 2011. Climatic constraints on wintering bird distributions are modified by urbanization and weather. Journal of Animal Ecology 80:403-413. DOI: 10.1111/j.1365-2656.2010.01780.x. 
Zunckel k. 2003. Managing and Conserving Southern African Grasslands With High Endemism. Mountain Research and Development 23:113-118. DOI: 10.1659/0276-

4741(2003)023[0113:MACSAG]2.0.CO;2.

3

4

5

\section{Primary Files}

Figure 1 Map of study area showing location of our 500m x 500m random study plots (green dots) include plots on adjacent farms to Ingula property. This map was created using gplot2, lon and lat on the $\mathrm{y}$ and $\mathrm{x}$ axis both represents longitude and latitude respectively.

Google imagery (C2018 TerraMetrics.

Figure 2 Effect of average estimated prevailing weather conditions at the time of survey (observability) and date of survey on detection of each of the 12 species throughout the four austral summer months.

Figure 3 Estimated number of plots occupied (out of 19 plots) for each of the 12 bird species across the four summer months.

Figure 4 Hierarchical dynamic plot occupancy of the 12 most common species, showing influence of grass height and cover on persistence and colonization of each species during the austral summer survey during 2011/12 at Ingula. The thick place line represent average mean.

Figure 5 Bird species richness comparing Ingula farms that experienced relatively little grazing compared to neighbouring farms which were intensively grazed with cattle during the four summer months. Almost all plots both inside Ingula property and on adjacent farms were burned prior to summer but sometimes late into the summer breeding season.

\section{Supplemental files}

Appendix S1 Scoring of prevailing weather conditions (observability) each weighted according to how DHM based on knowledge of the area perceived a weather variable to influence detection of birds. Conditions were optimal with a clear sky (score $1=100$ ), cool temperatures (score $2=100$ ) and calm wind conditions (score $3=100$ ). For other weather conditions, observability was reduced and we chose the scores according to our subjective 
651 judgement of how much it affected our ability to detect birds. For example, observability was

652 similarly reduced in strong winds as in hot weather, etc. We then averaged the three scores to 653 get a single value for observability.

654 Appendix S2 Multi-Species, dynamic hierarchical model: R and BUGS code used to fit the 655 model. R script with the JAGS model specification for multi-species hierarchical occupancy 656 model with effect of grass height and grass cover on occupancy $(\Psi)$, persistence $(\varphi)$ and 657 colonisation $(\gamma)$ probabilities with additional effect of environment (cloud cover and wind) on 658 detection probability (p).

659

PeerJ 18932 Vegetation plot survey file - for grass height and grass cover summers 2010-2012 664

665 
Figure 1

Map of study area where green dots represent centre of each plots

Map of study area showing location of our $500 \mathrm{~m} \times 500 \mathrm{~m}$ random study plots (greendots) include plots on adjacent farms to Ingula property. This map was created using gplot2, lon and lat on the $y$ and $x$ axis both represents longitude and latitude respectively.

Google imagery @2018 TerraMetrics.

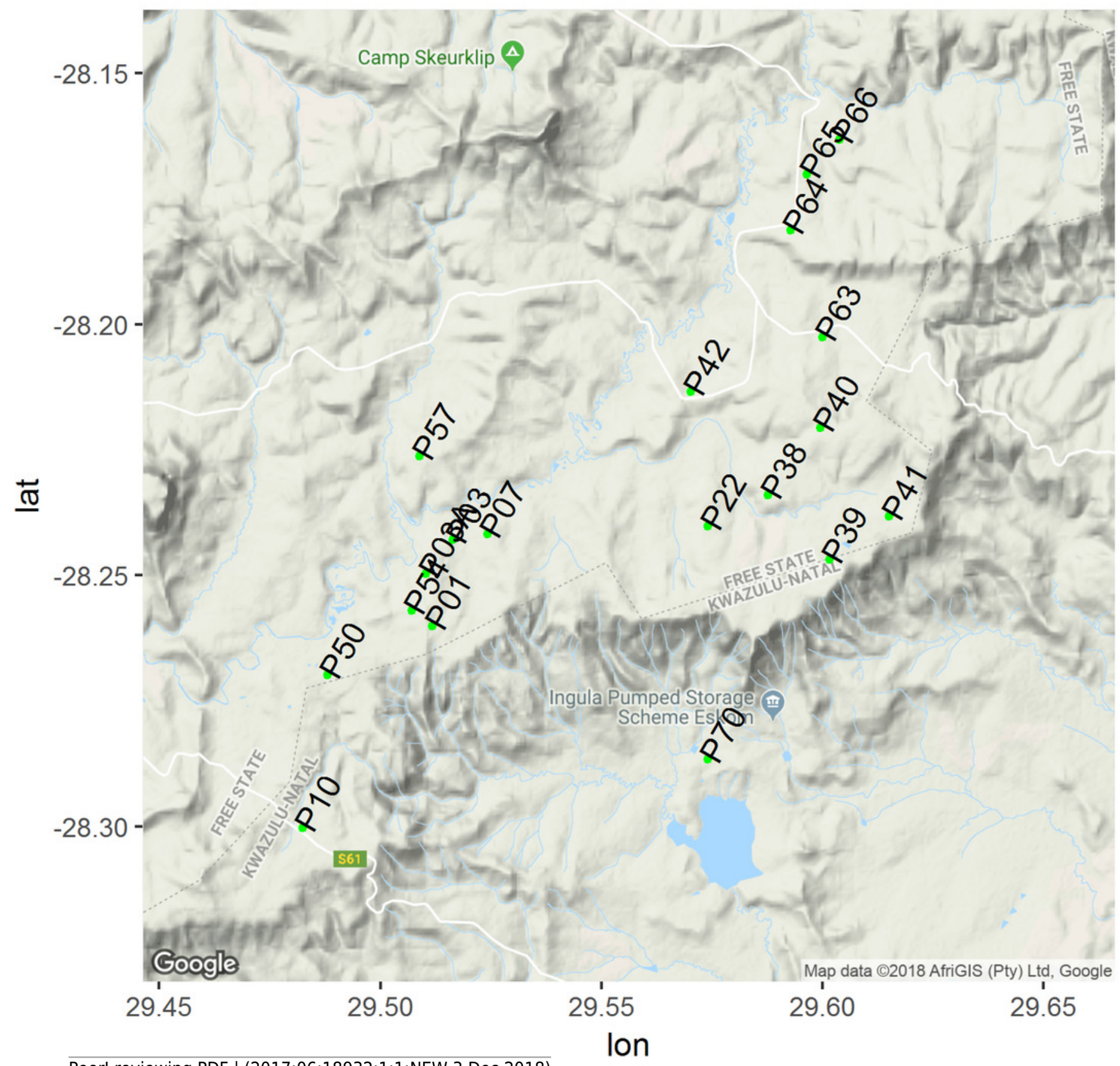


Figure 2 (on next page)

Effect of covariates on species detection for 12 birds

Effect of average estimated prevailing weather conditions at the time of survey

(observability) and date of survey on detection of each of the 12 species throughout the four austral summer months. 


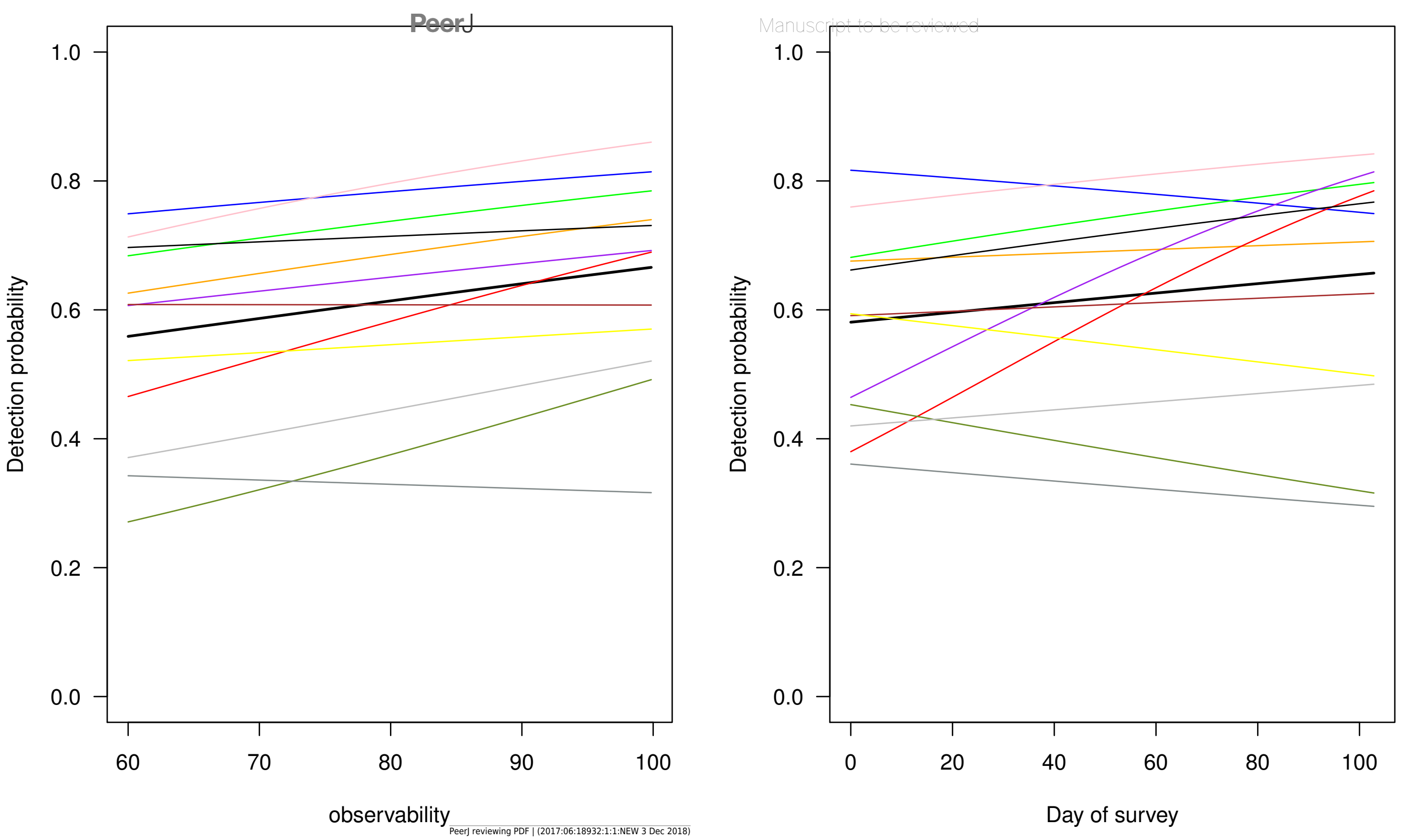


Figure 3 (on next page)

Number of plots occupied by each species out of 19 plots

Estimated number of plots occupied (out of 19 plots) for each of the 12 bird species across the four summer months. 

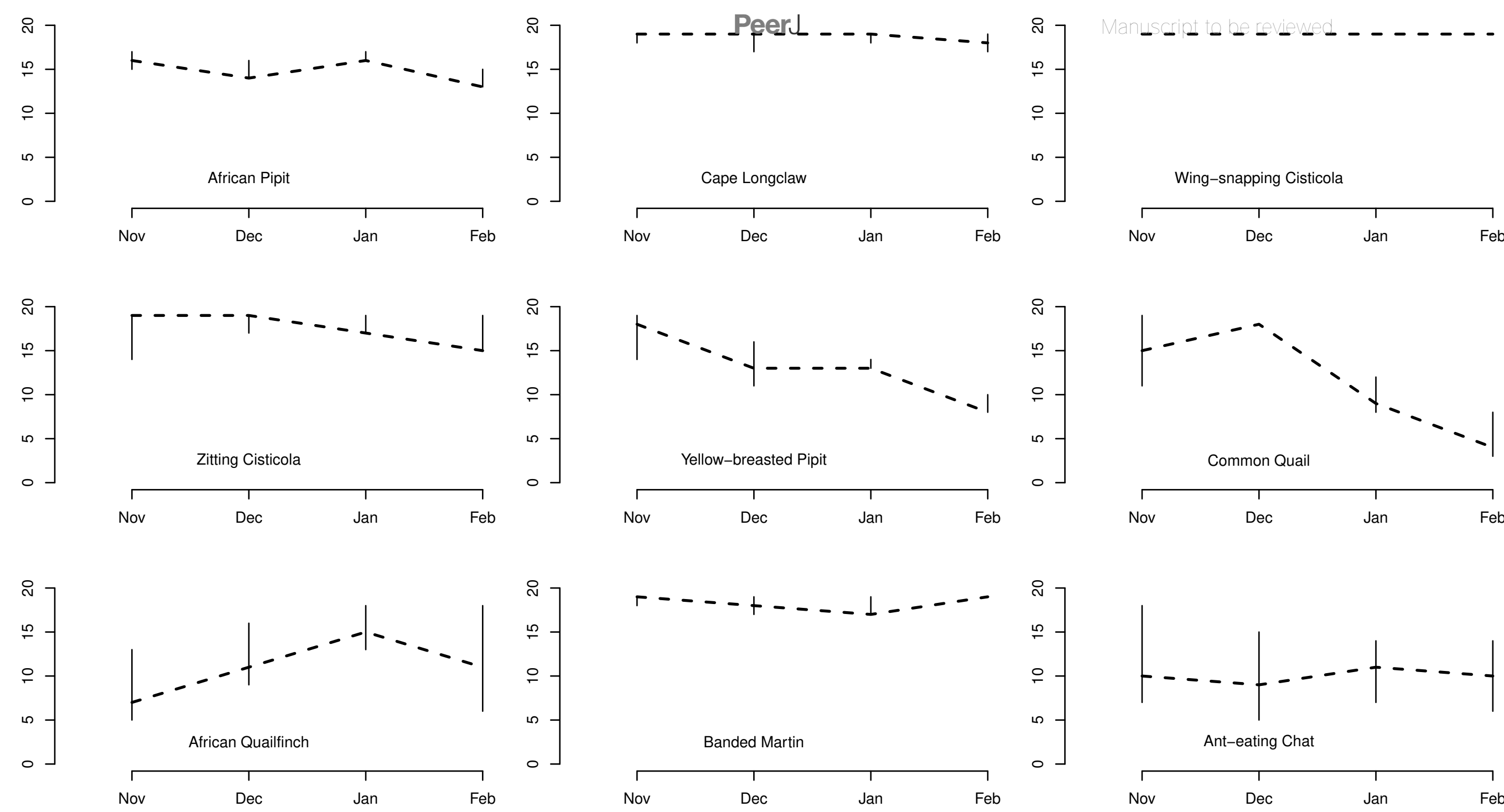
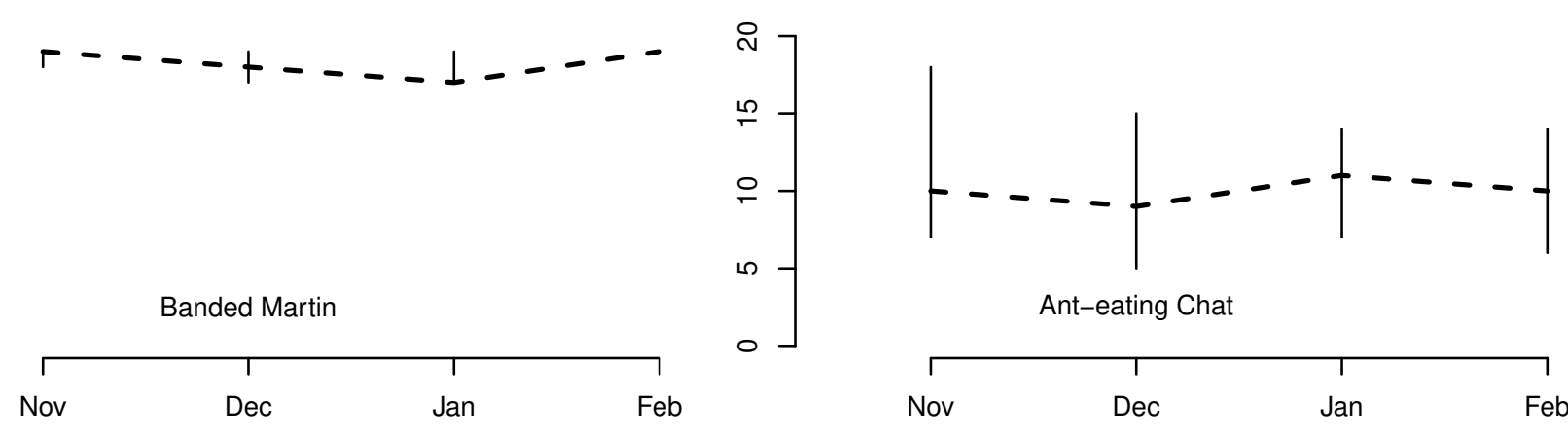
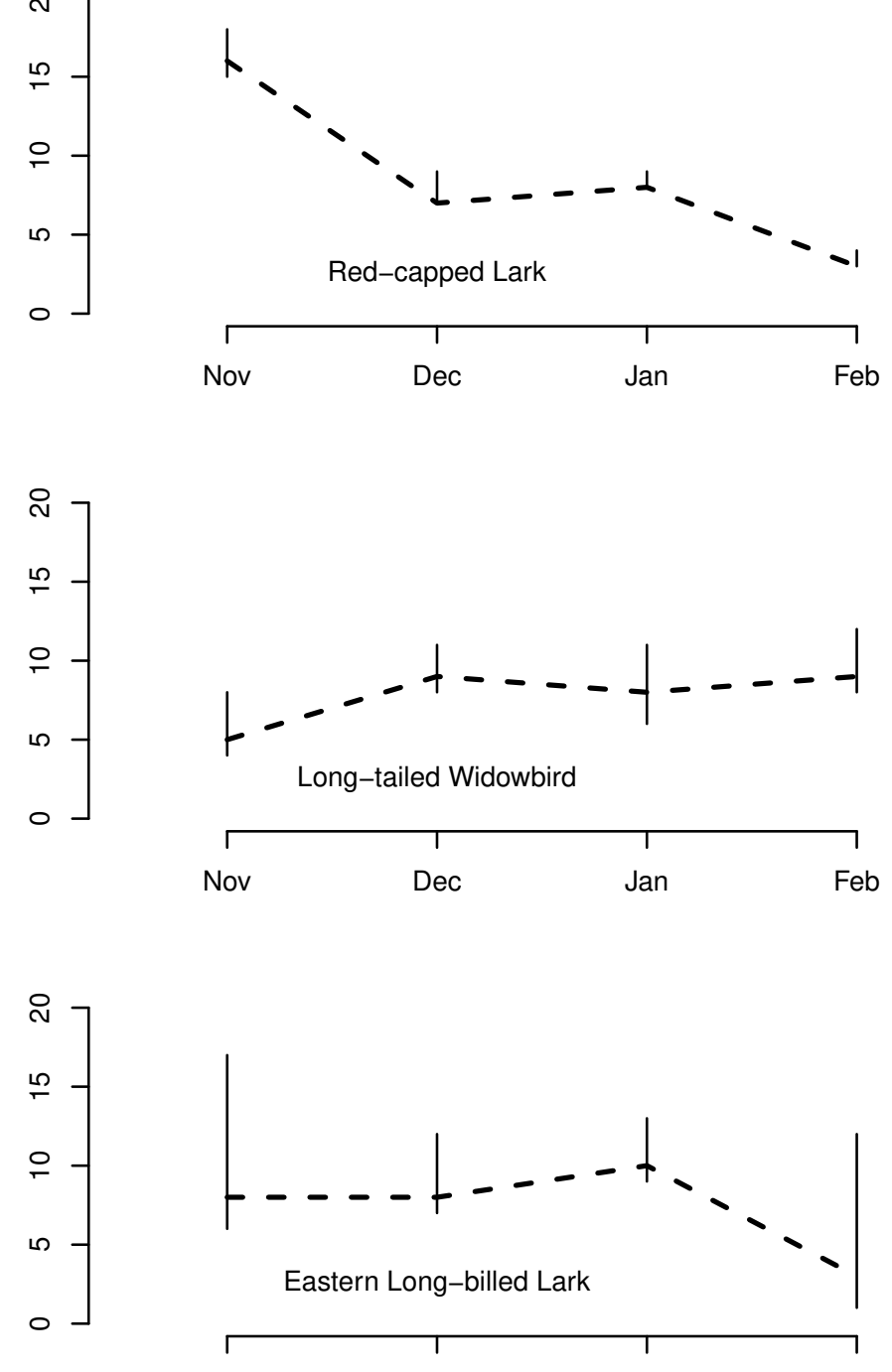

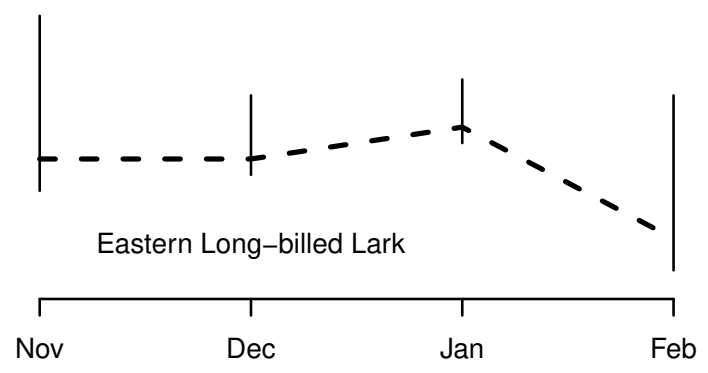




\section{Figure 4 (on next page)}

Effects of grass height and grass cover on occupancy

Hierarchical dynamic plot occupancy of the 12 most common species, showing influence of grass height and cover on persistence and colonization of each species during the austral summer survey during 2011/12 at Ingula. The thick place line represent average mean. 

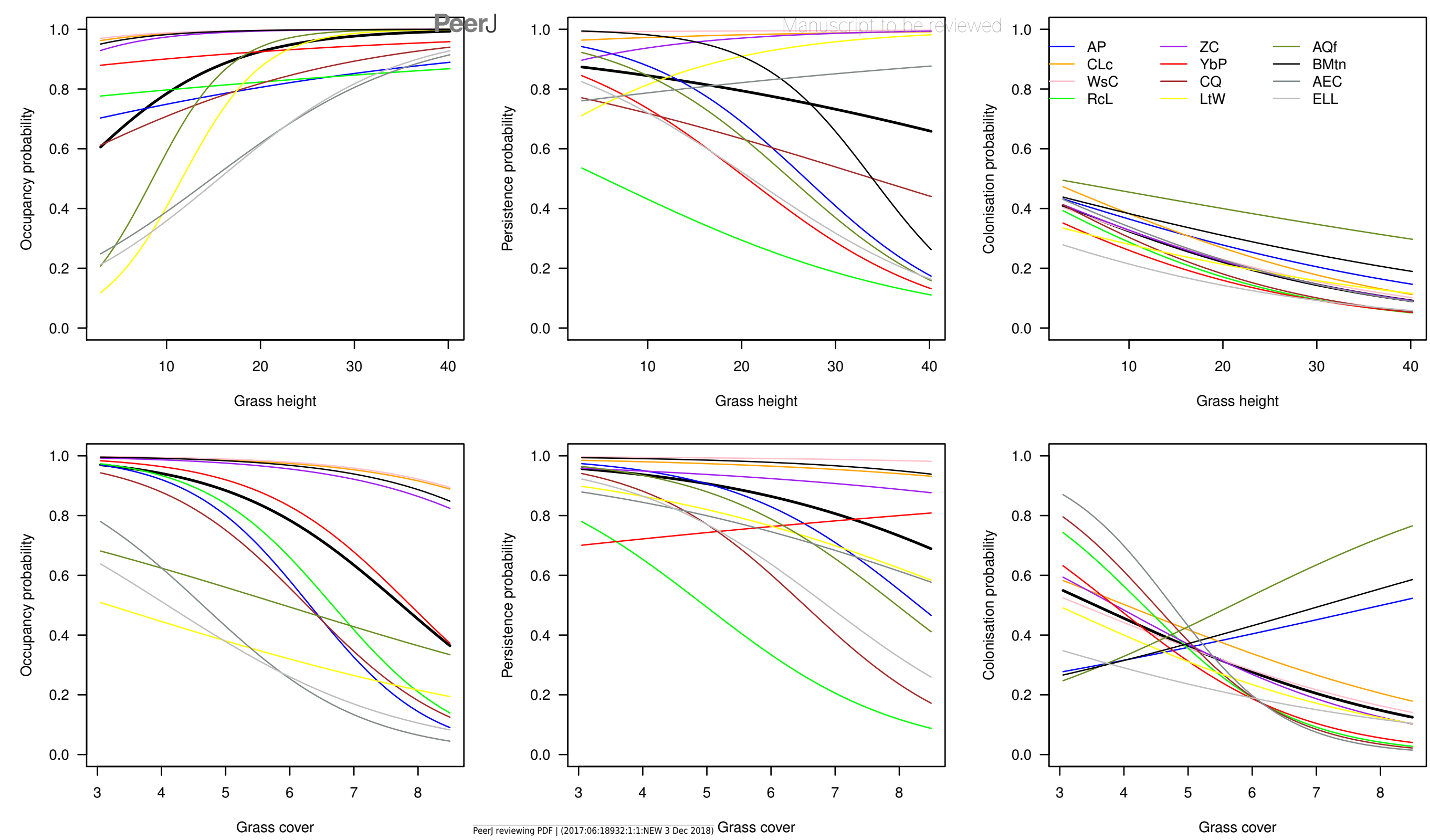
Figure $\mathbf{5}$ (on next page)

Response of each of the 12 species to grass height and grass cover

Bird species richness comparing Ingula farms that experienced relatively little grazing compared to neighbouring farms which were intensively grazed with cattle during the four summer months. Almost all plots both inside Ingula property and on adjacent farms were burned prior to summer but sometimes late into the summer breeding season. 


\section{PeerJ November \\ Manuscript to be reviewed}
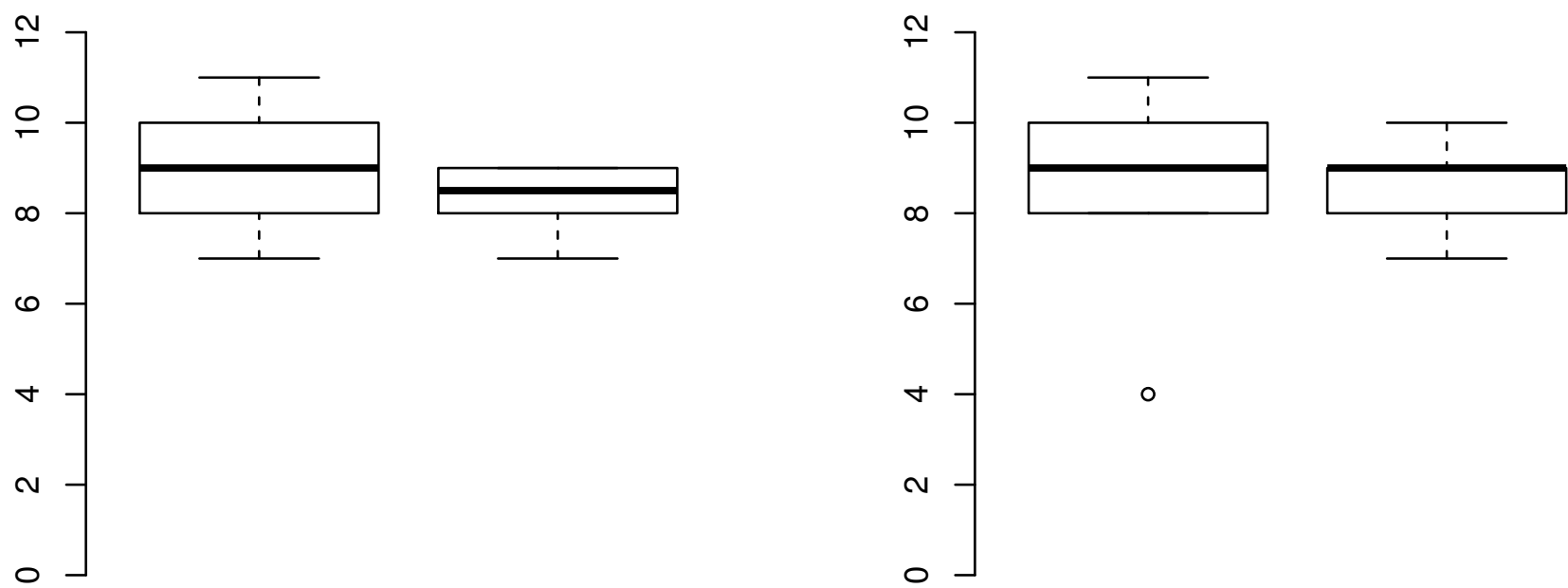

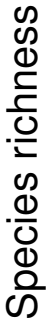

January
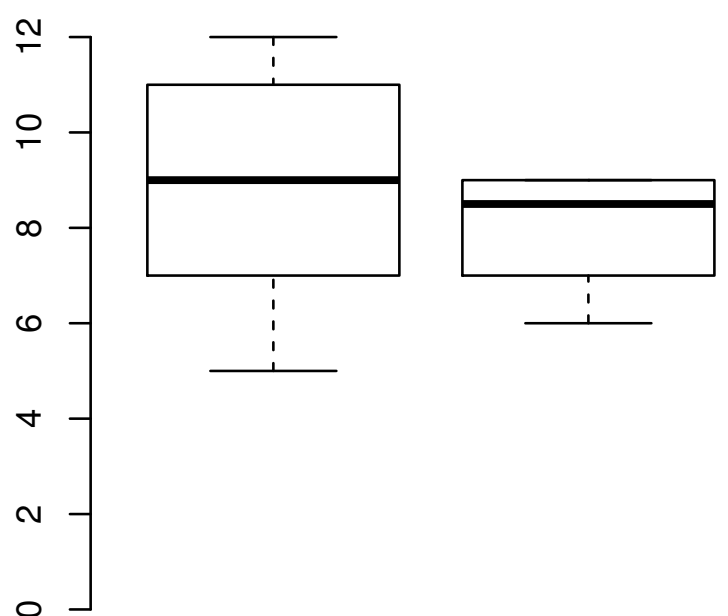

0

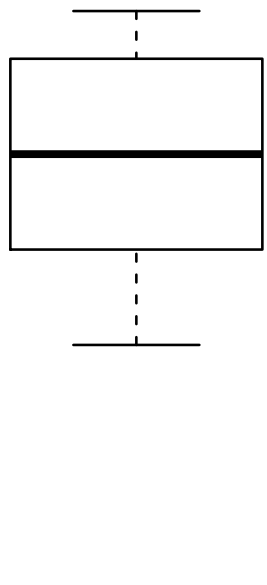

Eskom

Private

February
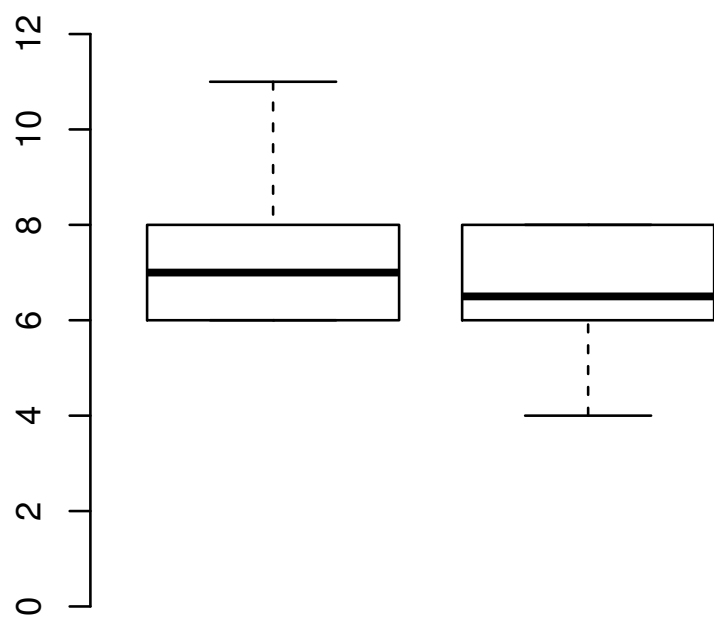

Eskom

Private 